Evica Delova Jolevska, $\mathrm{PhD}^{1}$

Ilija Andovski, $\mathrm{PhD}^{2}$

University American College, Skopje, Macedonia
SCIENTIFIC REVIEW ARTICLE

Received: November 17, 2014

Accepted: February 03, 2015

\title{
NON- PERFORMING LOANS IN THE BANKING SYSTEMS OF SERBIA, CROATIA AND MACEDONIA: COMPARATIVE ANALYSIS
}

\begin{abstract}
The aim of this paper is to evaluate the level of NPL loans in banking systems of the three sample Balkan countries. The special attention is dedicated to the level of NPL loans and their ratio compare to total loans. The quality of credit portfolio is important determinant in future bank strategies, thereby it's important for the economic development of the whole country. The NPL loans affect the economic development through the credit activity which influence on the consumption and the capital adequacy ratio which constrain the possibility of growth. Thus creating a spiral and higher NPL ratio create low economic growth and low growth creates further NPL portfolio. In this paper analysis will be focused to compare the data of quality of credit portfolio in Macedonia, Serbia and Croatia. The comparative analysis will outline the differences in the quality of the portfolios in sample countries as well as the reasons for the differences. The reasons for higher resilience of some banking systems portfolios compared to others can be used as a valuable tool for enhancing the stability of the banking systems. These three countries are chosen because they had high credit growth in the past until the financial crises, they were affected by the crisis in the same time and their banking systems are dominantly owned by foreign banks.
\end{abstract}

Keywords: Credit portfolio, NPL, banking systems, growth rate

JEL classification: G21, G01

\section{НЕНАПЛАТИВИ КРЕДИТИ У БАНКАРСКОМ СИСТЕМУ СРБИЈЕ, ХРВАТСКЕ И МАКЕДОНИЈЕ КОМПАРАТИВНА АНАЛИЗА}

\begin{abstract}
Апстракт
Циљ овог рада је да се процени степен ненаплативих кредита (НПЛ) кредита у банкарским системима три узорка из три балканске земље. Посебна пажна је посвећена нивоу ненаплативих (НПЛ) кредита и юихов однос у поређењу са укупним кредитима. Квалитет кредитног портфолија је битна
\end{abstract}

\footnotetext{
1 jolevski2001@yahoo.com

2 iandovski@yahoo.com
} 
одредница у будућим стратегијама банака, то је важно за економски развој иеле земље. Ненаплативи кредити (НПЛ) могу утищати на економски развој кроз кредитне активности које утичу на потрошьу и стопе адекватности капитала који ограничавају могућност раста. Стварајући спиралу и већу ненаплативост кредита (НПЛ) створа се низак привредни раст а низак раст ствара додатну ненаплативост кредита (НПЛ) портфолио. У анализи овог рада бићемо фокусирани на упоредне податке квалитета кредитног портффолија у Македонији, Србији и Хрватској. Компаративна анализа ће нагласити разлике у квалитету портфолиа на узорку земаља, као и разлоге за разлике. Разлози за високу отпорност неких банкарских система портфолија у односу на друге може да се користи као драгоцено средство за јачање стабилности банкарског система. Ове три земље су одабране јер су имале висок кредитни раст у прошлости до финансијске кризе, оне су погођена кризом у исто време и њихови банкарски системи су доминантно у власништву страних банака.

Кључне речи: Кредитни портфолио, ненаплативи кредити (НПЛ), банкарски системи, стопа раста.

\section{Introduction}

The banking sector is considered to be an important source of financing for most businesses. According to Dreca (Dreca, 2012), the increase in the financial performance leads to more improved functions and activities of any organization. The condition on banking system has effect on total economy of the country (Dreca, 2012), because banks are the sources of finance for better job opportunities, development of new ideas; research and overall prosperity. The factors that influence performance of banks are: bank size measured by its assets, profitability measured by returns on assets and equity, size of deposits and loans, as well as the percentage of non- performing loans in the total loans.

Recent transatlantic financial crisis experience suggests that the state of the banking sector and developments in real economy are strongly interconnected. The nonperforming loans are one of the major causes of the economic stagnation problems. Each non-performing loan in the financial sector is viewed as an obverse mirror image of an ailing unprofitable enterprise (Hou \& Dickinson, 2007). From this point of view, the reduction of non-performing loans is a necessary condition to improve the economic status. If the non-performing loans are kept existing and continuously rolled over, the resources are locked up in unprofitable sectors; thus, hindering the economic growth and impairing the economic efficiency. Also the impairment for bad loans decreases the solvency position and the risk profile of the banks. Refraining from lending, through decreased consumption and bankrupt companies, further lowers economic activity and lower economic activity produces more NPL loans. So a spiral is created that which harms the banking system and the economy as a whole.

The literature identifies two sets of factors to explain the evolution of NPLs over time (IMF, 2013). According to IMF, the one group focuses on external events such as 
the overall macroeconomic conditions, which are likely to affect the borrowers' capacity to repay their loans, while the second group, which looks more at the variability of NPLs across banks, attributes the level of non-performing loans to bank-level factors. The econometric analysis of the empirical determinants of NPLs presented suggests that real GDP growth was the main driver of non-performing loan ratios during the past decade. Therefore, a drop in global economic activity remains the most important risk for bank asset quality (ECB, 2013). Some other authors connect the NPL loans with the intensity of credit growth in the past (Espinoza \& Prasad, 2010), the leverage of corporate clients (Glen \& Mondragón-Vélezand, 2011) or unemployment rate (Louzis, Vouldis \& Metaxas, 2010). So the level of NPL loans can be affected by different macroeconomic factors which require careful analysis of the reasons for their occurrence.

The boom-bust cycle has left a legacy of high non-performing loans (NPLs) in various countries in Central, Eastern and Southeastern Europe ("Vienna" Initiative, 2012). Very high credit growth during 2003-08 gave rise to an unsustainable boom that ended abruptly with the global financial crisis of 2008/09. The high credit growth was followed by deep recession that brought many of the accumulated underlying problems to the fore, including poor quality of some loans in banks' books. This paper will determine the quality of credit portfolio in three sample Western Balkan countries: Macedonia, Serbia and Croatia. The aim of the analysis will be to reveal the differences in NPL level in the sample countries in order to discover the reasons for these differences. The analysis of the quality of the credit portfolio has obligatory included the share of NPL loans. In all sample countries the definitions for NPL loans are similar which is precondition for comparative analysis. Loan is considered non-performing when is has not been collected in more than 90 days from the date of maturity. Another important aspect in the NPL ratio analysis is the credit growth. In period of low credit growth the NPL ratio grows because the denominator in the equation remains unchanged and the natural process of aging of the portfolio produces growth of NPL loans. The analysis will be conducted by segments, corporate loans and retail loan with the conclusions about the resistance of each portfolio.

\section{NPL in Serbian banking system}

The structure in the credit portfolio in Serbia is in favor of corporate loan with share of 57\%, while the retail loans participate with 43\% (Central Bank of Serbia, 2014). This structure has remained unchanged in the last 6 years.

The analysis of the corporate portfolio shows that the banking system is dominantly exposed toward manufacturing (29\%) and trade $(25 \%)$ (Figure 1$)$. Next by size are the portfolios of transport industry (14\%) and construction $(9,9 \%)$. The share of trade industry is large and is determined by the economic development. More developed economy has developed industry which needs credit support. Also the industry sector is more financially extensive and bigger credit support is needed. In deficiency of strong industrial sector who can export its goods, Serbian banks are turned towards wholesale and retail trade sectors (Jolevska \& Andovski, 2014).

Regarding the retail portfolios, housing loans are dominant with $47 \%$ share (Figure 1). Second portfolio by size is the consumer loan portfolio with $26 \%$ share. The size of housing loan portfolio is indicator of expectations for good prospects in the past. 
Figure 1: Structure of retail and corporate portfolios
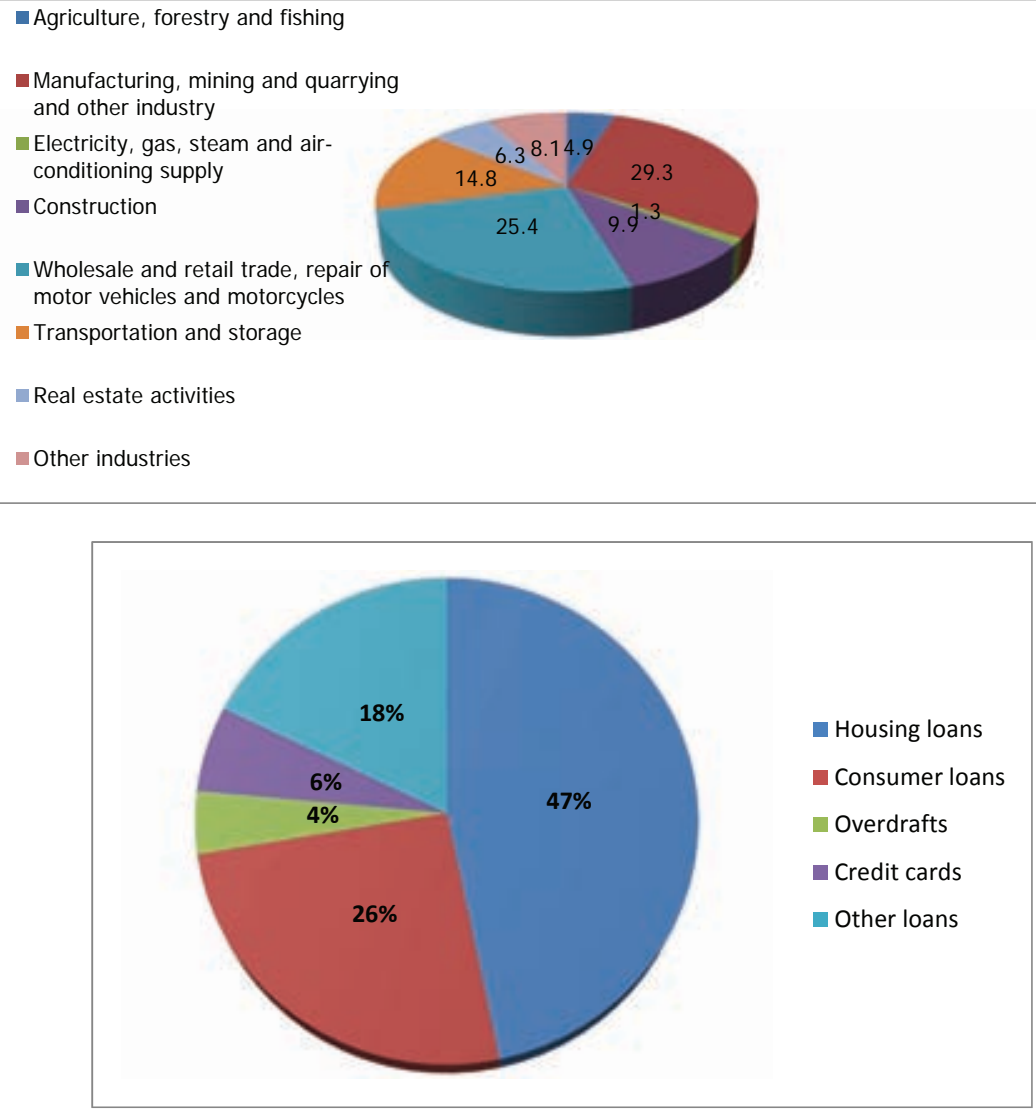

Source: Banking sector of Serbia, Fourth Quarter Report 2013, Central Bank of Sebia

As it is mentioned earlier, another aspect for the analysis of NPL loans ratio is the credit growth. As can be seen in Figure 2, the Serbian banking sector marked double-digit growth before 2009. The effects of the global financial crisis were anticipated late and during the end of 2009 the growth was under 3\%. 2013 has a trend of decline in the loan portfolio, especially at corporate loans. According to Filipovic and Hadžić (Filipovic \& Hadžić, 2013) the Global Crisis has started to influence the national economy at the late 2008 and first negative impact was reported even before on Belgrade stock exchange, when foreign investors simply left the market. The banking sector was in better shape than in other transitory economies, considering high capital adequacy ratio, satisfied liquidity, safe deposits and low risk. The Central Bank has introduced urgent measures in order to increase liquidity and concluded so - called Wiener agreement with foreign banks, which prevailed in the banking sector. The measures introduced by the Central bank and by the Government were in right direction, but weak and the solution to overcome the crisis safely was seen in stand - by arrangement with IMF. 
Figure 2: Credit growth in Serbian banking system

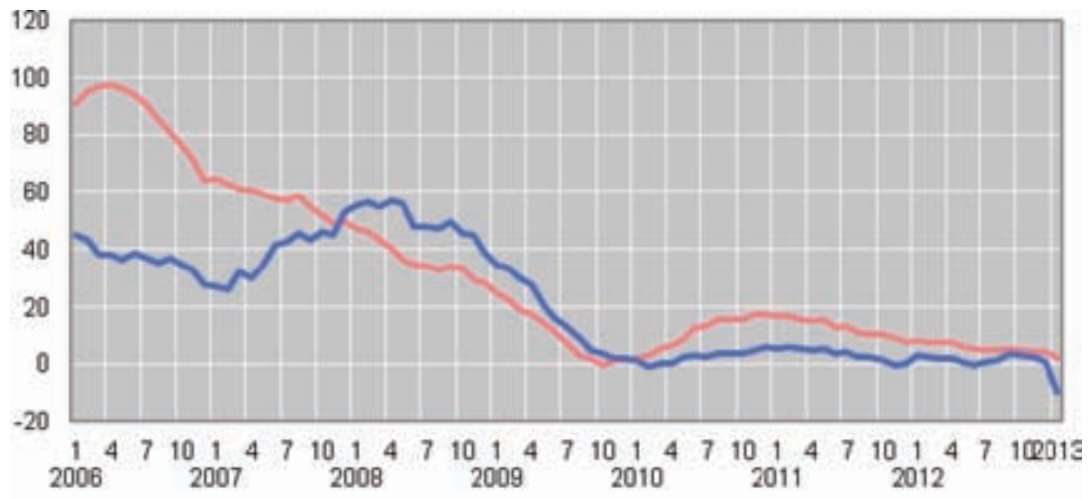

Retail loans Corporate loans

Source: Annual Financial Stability Report - 2013, Central Bank of Sebia

The NPL ratio in Serbian banking system at the end of 2013 was $21 \%$. The main driver of the high level of NPL loans were corporate loans. The world financial crisis had negative impact on banking figures starting from 2009. Still, in 2008 the NPL ratio in Serbia was higher than $11 \%$ which was due of the high credit growth in the past. The effects of the financial crisis were 10 basis points higher NPL ratio.

Table 1: Share of NPL in total loans in corporate sector in Serbian banking sector

\begin{tabular}{l|rrrr}
\hline Share of NPL in total loans & \multicolumn{1}{|c}{ Q4 } & Q4 & \multicolumn{1}{c}{ Q4 } & Q3 \\
\hline Agriculture, forestry and fishing & \multicolumn{1}{|c}{ Q10 } & 2011 & 2012 & \multicolumn{1}{c}{2013} \\
Manufacturing, mining and quarrying and other industry & $36.80 \%$ & $29.80 \%$ & $17.20 \%$ & $15.40 \%$ \\
Electricity, gas, steam and air-conditioning supply & $23 \%$ & $24.50 \%$ & $18.50 \%$ & $25.20 \%$ \\
Construction & $3 \%$ & $3 \%$ & $3.70 \%$ & $3.20 \%$ \\
Wholesale and retail trade, repair of motor vehicles and motorcycles & $19 \%$ & $26.70 \%$ & $45.10 \%$ & $53.00 \%$ \\
Transportation and storage & $20 \%$ & $22.50 \%$ & $17.50 \%$ & $29.00 \%$ \\
Real estate activities & $16 \%$ & $14.20 \%$ & $8.50 \%$ & $13.90 \%$ \\
Other industries & $23.40 \%$ & $38.30 \%$ & $37.40 \%$ & $40.00 \%$
\end{tabular}

Source: Banking sector of Serbia, reports2010-2013, Central Bank of Serbia

The construction was the most affected industry with 53\% NPL ratio and real estate activities with $40 \%$ NPL ratio (Table 1). The manufacturing industry felt the financial crisis first because of the small quantities of export at EU partners. In the last year there is deterioration in the credit worthiness of client from retail industry. Further declining in banking support will create new NPL loans and further deterioration in the economic activity of whole economy.

Regarding the retail portfolio, this portfolio is with the better quality (Table 2). The product that has higher level of NPL is over draft which is due of increasing of the unemployment rate. Also credit cards and consumer loans NPL ratios have upside trend and are due of aging of the portfolio which was created before 2008. 
Table 2: Share of NPL in total loans in retail sector in Serbian banking sector

\begin{tabular}{l|cccc}
\hline Share of NPL loans & 2010 & 2011 & 2012 & 2013, Q3 \\
\hline Housing loans & $6 \%$ & $6 \%$ & $6 \%$ & $7 \%$ \\
Consumer loans & $9 \%$ & $9 \%$ & $13 \%$ & $12 \%$ \\
Overdrafts & $15 \%$ & $16 \%$ & $14 \%$ & $14 \%$ \\
Credit cards & $11 \%$ & $12 \%$ & $12 \%$ & $13 \%$ \\
Other loans & & & $18 \%$ & $18 \%$
\end{tabular}

Source: Banking sector of Serbia, reports2010-2013, Central Bank of Serbia

According to Filipovic and Hadžić (Filipovic \& Hadžić, 2013) development of Serbian banking sector is limited now by weak corporate sector and low income citizens. Banks, for time being, found solution into reorientation of crediting from corporate sector, as too risky, to government and public sector, as less risky. However, it is not long lasting solution. The enhancement of real economy and public sector can open room for further development of the banking sector, which one can expect to be only performed in circumstances of global recovery.

\section{NPL in Croatian banking system}

The loan portfolio of Croatian banks is dominated by retail loans (Central Bank of Croatia, 2014). This fact indicates for possible indebtedness of the population and is not in function of economic development.

In retail loan structure dominant portfolio, with almost 50\% share, is the housing portfolio which was created before 2008 in perception of good prospects of the economy. The second largest portfolio is the consumer loans portfolio. The corporate portfolio is dominated by construction industry portfolio with $26 \%$ share and trade with $18 \%$ (Figure 3 ).

Figure 3: Structure of retail and corporate portfolios

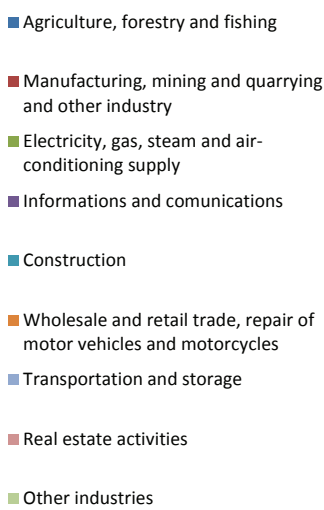

Other industries

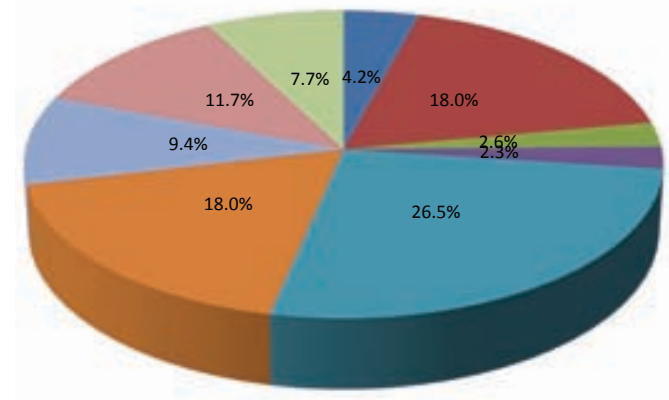




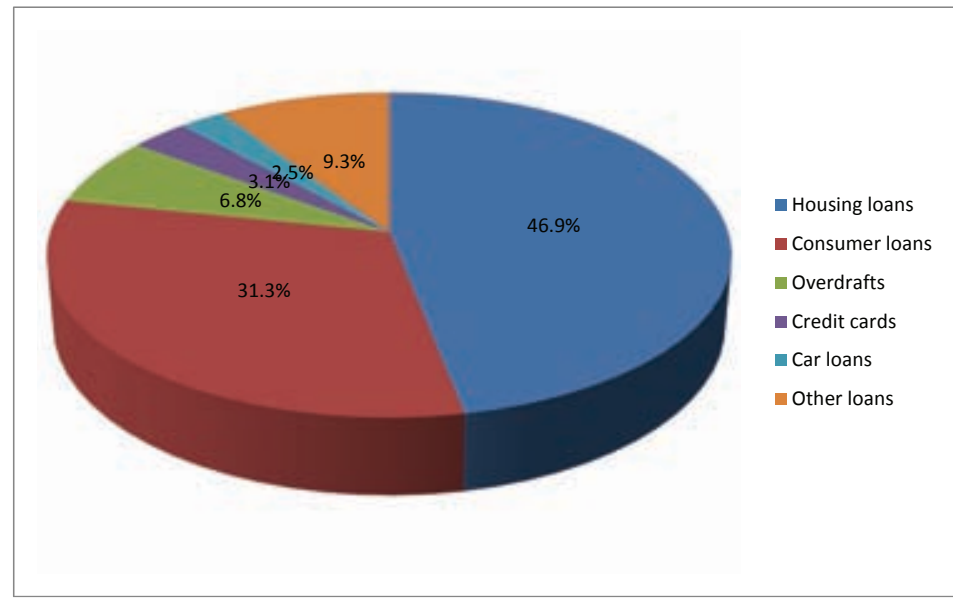

Source: Banks Bulletin for 2013, Central Bank of Croatia

The Croatian banking system in the last two years was in a process of deleveraging which was due of the high NPL rates but also from Basel III standards and their effects on the parent bank companies. This process is the mostly present at corporate portfolio where in 2012 there was decrease of the size of portfolio for 15\% but the retail portfolio recorded negative growth rates, too (Figure 4).

Figure 4: Growth in credit exposure by segments for period 2002-2012

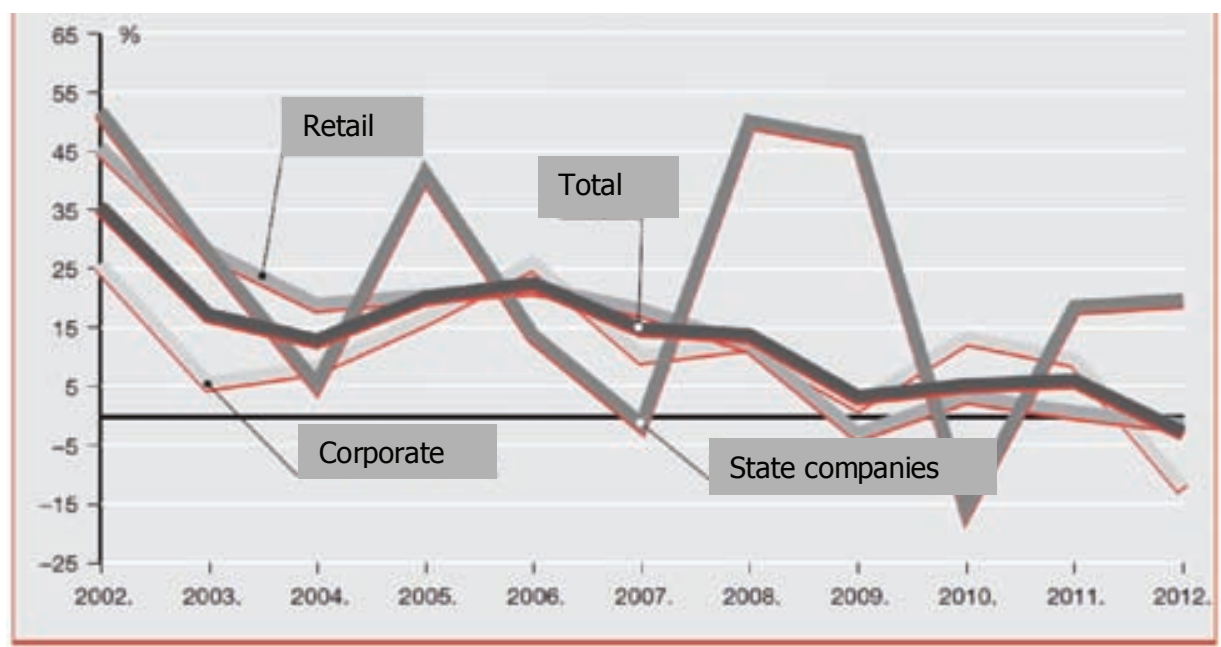

Source: Financial stability report for 2012, Central Bank of Croatia

The level of NPL loans at the end of 2013 is $15 \%$ and the trend is upward constantly. The main drivers of the NPL ratio are corporate loans with $27 \%$ NPL ratio (Figure 5). Of course, the high level of NPL loans is due of the structure of corporate 
portfolio where the construction portfolio has biggest share. What reflect the creditability of the population are consumer loans where the NPL ratio is around $25 \%$ and the trend is upward, too. But the quality of this portfolio is due of the huge credit expansion before 2008 and not only on financial crisis. The NPL ratio of this portfolio before 2009 was around 10\% which was double than the riskiness of total loan portfolio in 2008.

Due to the prolonged recession, NPL ratio in Croatia is becoming an increasingly important determinant of banking sector performance. According to Central Bank of Croatia (Central Bank of Croatia, 2013), on one hand, the value adjustment costs are burden on banks' capital, and on the other hand the NPL assets immobilize a considerable share of banks' balance sheets by burdening current or potential future credit growth. All Croatian banks in this period are particularly focused on recovery of NPL assets. Still, (Central Bank of Croatia, 2013) Croatia is in the group of countries where creditors spend an above average amount of time for collecting claims. So we can't expect fast reduction in NPL ratio.

Figure 5: Level of NPL loans by segments in Croatian banking system

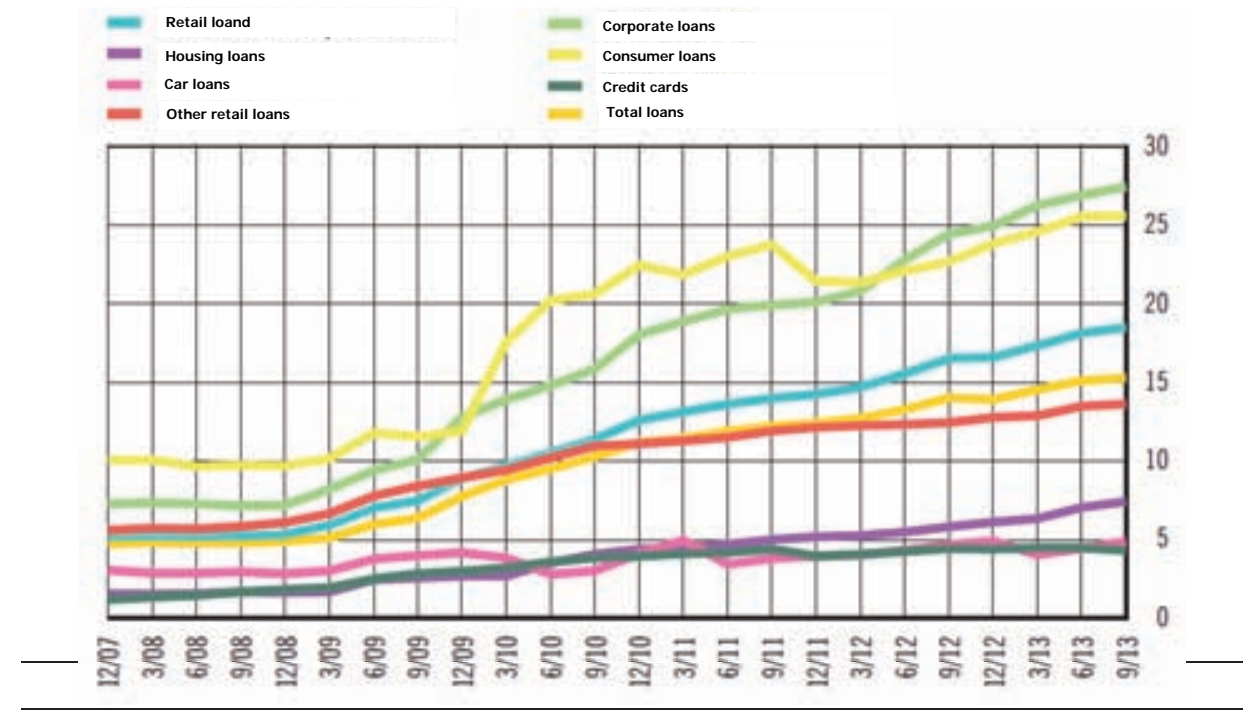

Source: Banks Bulletin for third quarter of 2013, Central Bank of Croatia

\section{NPL in Macedonian banking system}

At the end of 2013 the structure of loan portfolio is in favor of corporate loans with $61 \%$ share (NBRM, 2014). This structure hasn't been changed in the last 5 years. 
Figure 6: Structure of corporate and retail credit portfolio in Macedonian banking sector

Agriculture, forestry and fishing
Mining
Manufacturing, mining and
quarrying and other industry
Electricity, gas, steam and air-
conditioning supply
Construction
Wholesale and retail trade,
repair of motor vehicles and
motorcycles
Transportation and storage
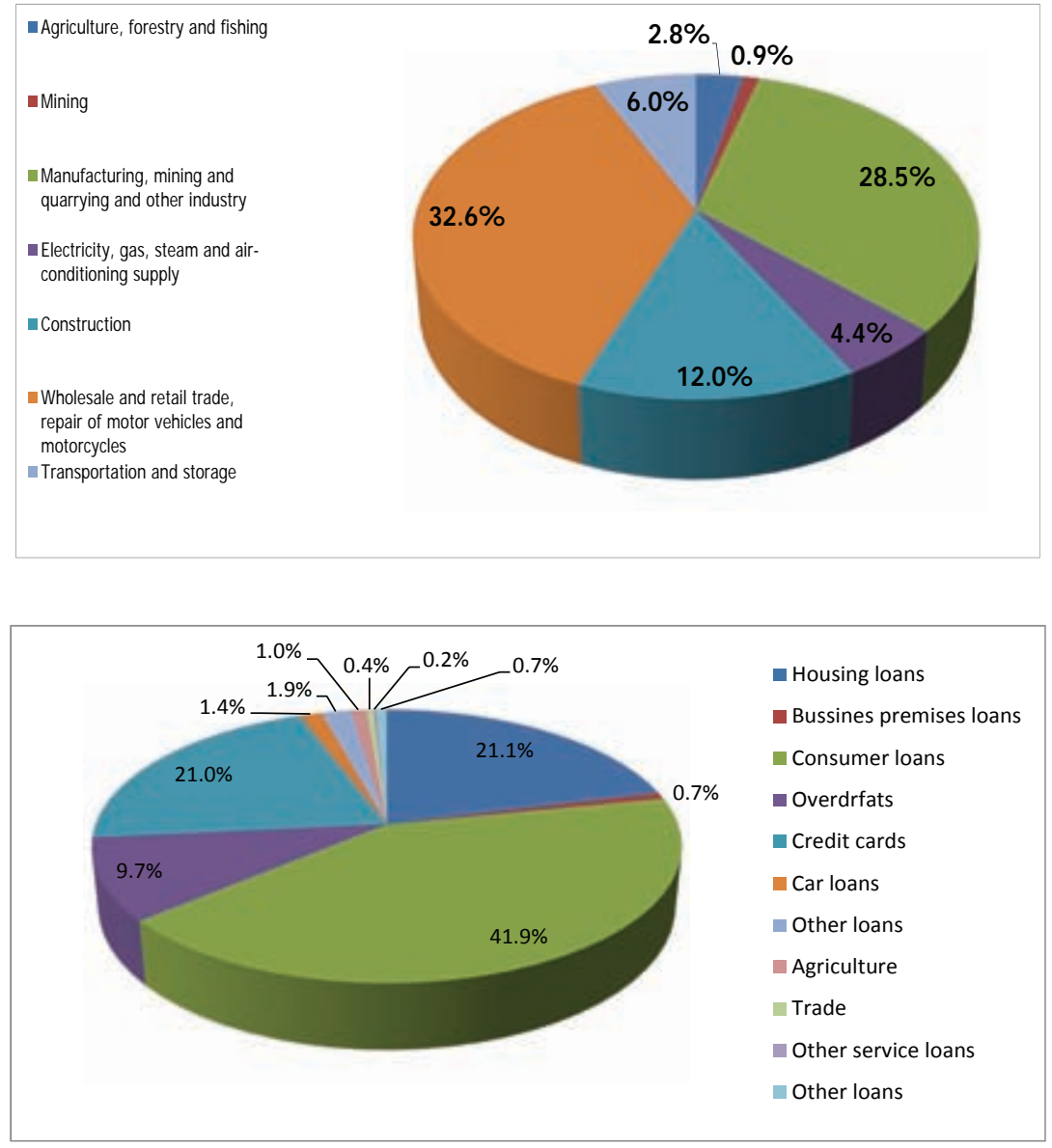

Source: Report on the risks in the banking system of the Republic of Macedonia in 2013, NBRM

The corporate portfolio is dominated by trade industry with $33 \%$ share, manufacturing industry with $29 \%$ share and construction with 12\% share (Figure 6). Regarding the retail portfolio, the structure is different from the other sample countries. Dominant portfolio is the consumer loan portfolio with $42 \%$ share, followed by credit card portfolio and housing portfolio with $21 \%$ share both. So, the structure of the portfolio is trait of the economy, in absence of strong industry, the trade portfolio is dominant corporate portfolio and weak power consumption at citizens resulted in big consumer loans and credit card portfolio instead of housing portfolio.

The financial crisis had impact on Macedonian banking system starting from 2009 when the rates of growth were single-digit numbers (Figure 7). 
Figure 7: Growth in credit exposure by segments in Macedonian banking system for period 2008-2013

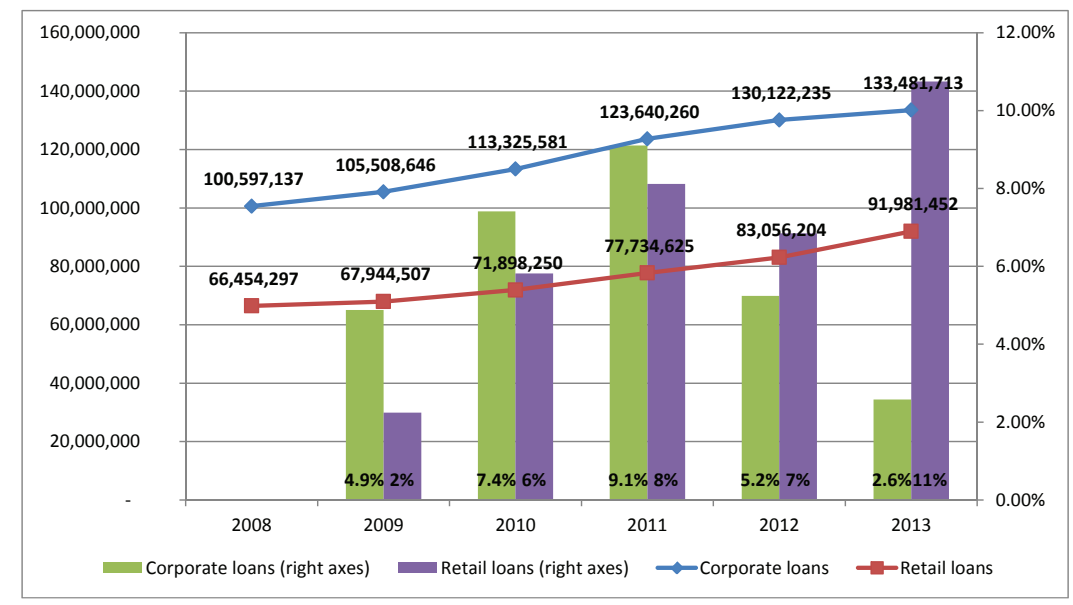

Source: Report on the risks in the banking system of the Republic of Macedonia 2008-2013, NBRM

Until 2011 the credit support was directed toward corporate sector. But, the continuing effects of the financial crisis and then the debt crisis in EU resulted in upward trend of NPL loans so starting from 2012 the retail credit portfolio had bigger rates of growth.

Macedonian banking sector was encountered by the financial crisis with $8 \%$ NPL ratio at corporate portfolio and 5\% at retail portfolio (Figure 8 ). In the next two years the retail NPL had bigger growth which was due more of weak standards which created this portfolio before 2008. The real effects on corporate portfolio of continuing weak economic activities the corporate sector felt in 2012 and 2013 when the NPL ratio was $15 \%$. Of course, the NPL ratio is growing because of the smaller credit support in this segment.

Figure 8: NPL ratio by segments in Macedonian banking system for period 2008-2013

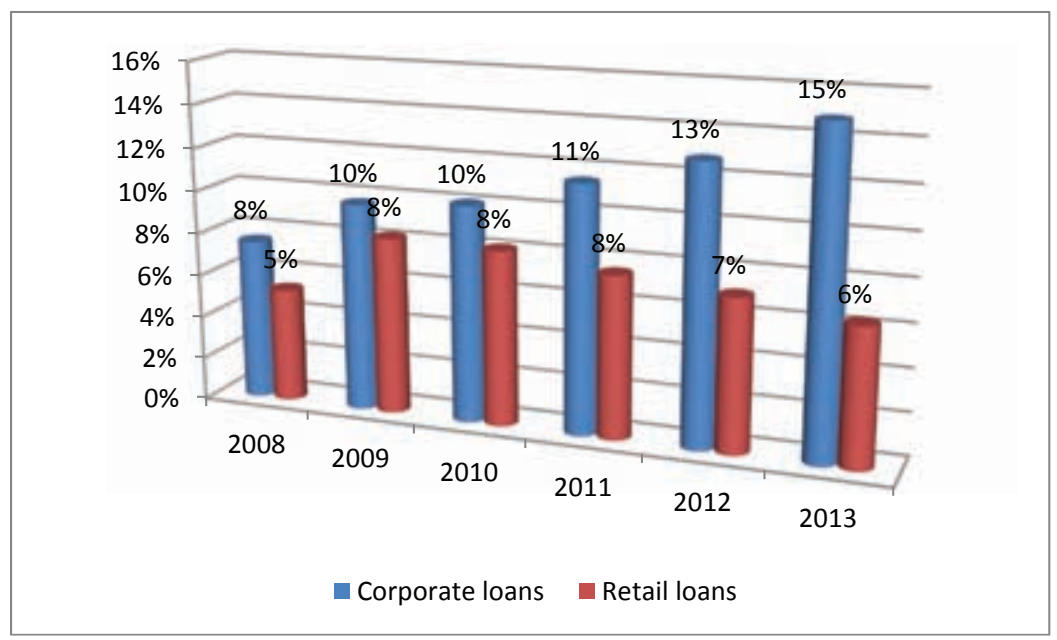

Source: Report on the risks in the banking system of the Republic of Macedonia 2008-2013, NBRM 
Quite opposite, after the loans at over indebted clients were cleared, the banking sector continued with credit support of retail sector and the NPL ratio in last two years felt. The industry analysis shows that manufacturing industry was first that felt the negative implications from the financial crisis and then debt crisis. Also like in the other sample countries the construction is the second most risky portfolio.

Table 3: NPL ratio by industry in corporate portfolio in Macedonian banking system on 31.12.2013

\begin{tabular}{|c|c|c|c|c|c|c|c|}
\hline & 2008 & 2009 & 2010 & 2011 & 2012 & 2013 & $\begin{array}{l}\text { Share in total } \\
\text { NPL }\end{array}$ \\
\hline $\begin{array}{l}\text { Wholesale and retail trade, repair of } \\
\text { motor vehicles and motorcycles } \\
\text { Manufacturing, mining and }\end{array}$ & $7 \%$ & $7 \%$ & $7 \%$ & $8 \%$ & $9 \%$ & $10 \%$ & $33 \%$ \\
\hline quarrying and other industry & $10 \%$ & $16 \%$ & $17 \%$ & $17 \%$ & $20 \%$ & $20 \%$ & $29 \%$ \\
\hline Construction & $10 \%$ & $7 \%$ & $7 \%$ & $10 \%$ & $18 \%$ & $18 \%$ & $12 \%$ \\
\hline $\begin{array}{l}\text { Transportation and storage } \\
\text { Electricity, gas, steam and air- }\end{array}$ & $5 \%$ & $8 \%$ & $7 \%$ & $9 \%$ & $12 \%$ & $9 \%$ & $6 \%$ \\
\hline conditioning supply & $0 \%$ & $0 \%$ & $0 \%$ & $0 \%$ & $21 \%$ & $21 \%$ & $4 \%$ \\
\hline
\end{tabular}

Source: Report on the risks in the banking system of the Republic of Macedonia 2013, NBRM

In the retail segment car loans and credit cards are the most risky portfolios. The high level of car NPL loans is due because of significant reduction of the portfolio which resulted with growth of NPL ratio. Part of the credit cards portfolio by its characteristics is consumer loans and should be analyzed together. Still total NPL ratio at retail segment is 6\% which is indicator for better portfolio than the sample countries (Table 4).

Table 4: NPL ratio by product in retail portfolio in Macedonian banking system on 31.12.2013

\begin{tabular}{l|ccccccc}
\hline & & & & & \multicolumn{3}{c}{$\begin{array}{c}\text { Share in total } \\
\end{array}$} \\
\hline Consumer loans & 2008 & 2009 & 2010 & 2011 & 2012 & 2013 & NPL \\
\hline Housing loans & $7 \%$ & $11 \%$ & $10 \%$ & $8 \%$ & $8 \%$ & $6 \%$ & $42 \%$ \\
Credit cards & $2 \%$ & $4 \%$ & $4 \%$ & $3 \%$ & $3 \%$ & $3 \%$ & $21 \%$ \\
Overdrafts & $6 \%$ & $9 \%$ & $9 \%$ & $10 \%$ & $10 \%$ & $10 \%$ & $21 \%$ \\
Other loans & $8 \%$ & $8 \%$ & $8 \%$ & $8 \%$ & $8 \%$ & $8 \%$ & $10 \%$ \\
Car loans & $6 \%$ & $34 \%$ & $8 \%$ & $13 \%$ & $9 \%$ & $10 \%$ & $2 \%$ \\
& $2 \%$ & $5 \%$ & $7 \%$ & $8 \%$ & $10 \%$ & $14 \%$ & $1 \%$
\end{tabular}

Source: Report on the risks in the banking system of the Republic of Macedonia 2013, NBRM

\section{Comparative analysis}

The comparative analysis in sample countries shows better quality of retail loans despite corporate loans. NPL ratio in Macedonia is much better against the other sample countries (Figure 9). 
Figure 9: NPL ratios in sample countries by segments at the end of 2013

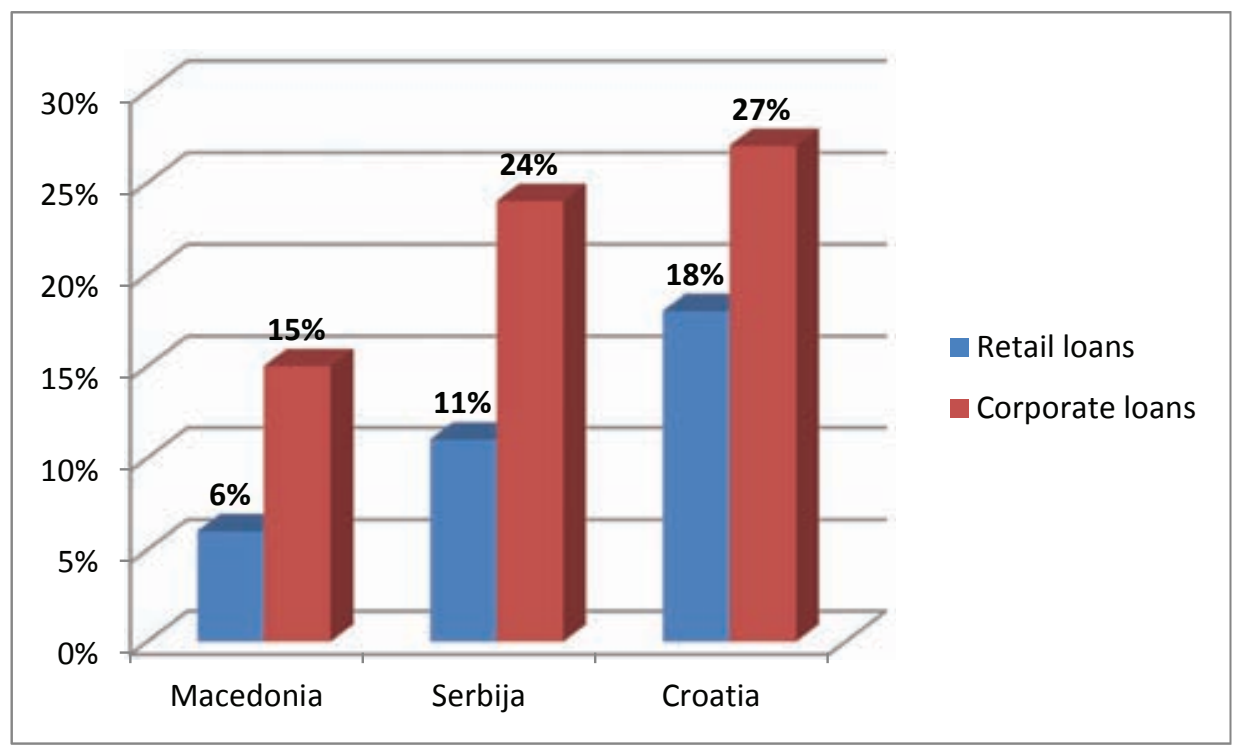

Source: Reports for banking systems for sample countries, 2013

The differences in quality of retail portfolio arising from two reasons: the level of exposure and the trend of unemployment rate. Macedonian citizens are least exposed as a percentage in GDP and per capita (Table 5). The double-digit rates of growth before 2008 with weakened credit standards copped the banking system with portfolio which was very vulnerable of economic activities. The country with highest retail loan portfolio compared to GDP has the banking system with the highest NPL ratio.

Table 5: Share of retail loans in GDP and exposure per capita in sample countries

\begin{tabular}{l|cc}
\hline & \multicolumn{2}{|c}{ Exposure per capita } \\
& Retail loans/GDP \% & in eur \\
\hline Bosnia & $27.3 \%$ & 939 \\
Croatia & $38.0 \%$ & 3,936 \\
Bulgaria & $24.0 \%$ & 1,318 \\
Macedonia & $15.6 \%$ & 727 \\
Serbia & $18.6 \%$ & 751
\end{tabular}

Source: CEE Banking Sector Reportfor 2013, Raiffesein Research

The other factor that affected the quality of retail portfolio was the unemployment rate (Figure 10). In Serbia and Croatia the unemployment rate after 2009 rose by 10 respectively 9 basis points. In Macedonia the unemployment rate for this period 
remained unchanged and even dropped by 3 basis points. The best indicator for trends in unemployment rate is the NPL ratio of overdrafts which depend on citizen wages. In Serbia and Croatia this ratio is around $15 \%$ and in Macedonia the NPL ratio of overdrafts is stable and is around $8 \%$.

Figure 10: Unemployment rate of sample countries
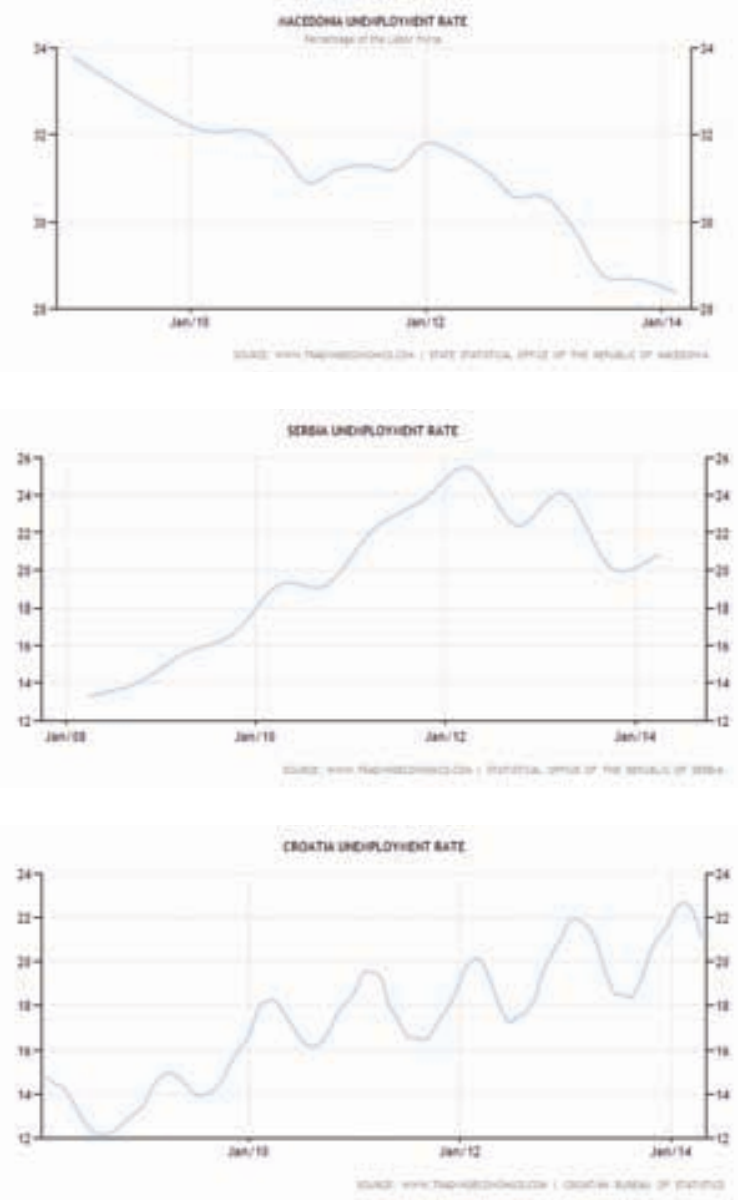

Source:www.tradingeconomics.com

The quality of corporate portfolio is predetermined by the previous credit activity before the financial crisis and the resistance of the economy of recession. Croatian banking system has highest NPL corporate ratio because it was exposed mainly toward construction industry which is first faced by impact of financial turmoil. This portfolio has worst quality in all three sample countries. The second factor is the exposure toward manufacture industry which is export oriented and dependent on orders from commercial partners mostly from EU countries. The third factor which is confirmed by numerous researches is the GDP movement and the resistance of the economy of negative economic 
movements. Croatia and Serbia economy had much more detrimental consequences from the financial crisis in 2009 than Macedonian economy (Figure 11). This trend continued until 2013. The banking system is mirror of the real economy and worsening economic performance had its impact on the banking systems.

Figure 11: GDP growth in sample countries for period 2004-2013

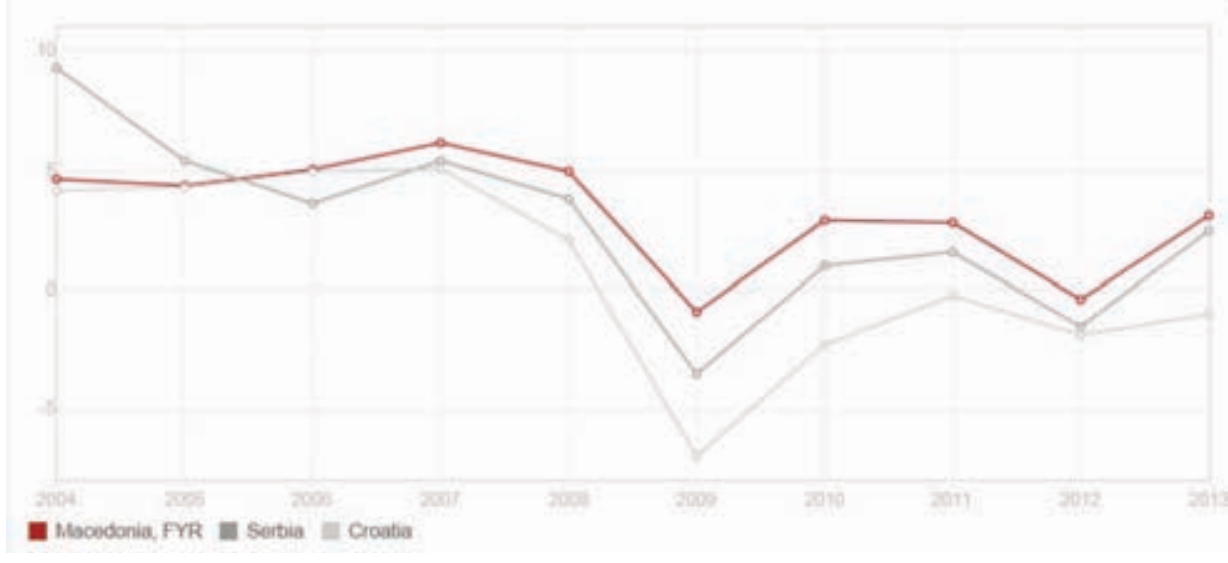

Source: World Bank statistics, 2014

\section{Conclusion}

The analyze in the three sample countries shows that the circumstances before the financial crisis that affected with high credit growth and the financial crisis and EU debt crisis had impact on the quality of credit portfolio. Still, although the trend of deterioration is present in all sample countries the intensity and effects are quite different. Most negative effects and greatest deterioration in the quality of portfolio is observed in Croatia. This is due to the structure of credit growth before the financial crisis. The banking sector largest portfolios are construction at corporate portfolio and housing loans at retail portfolio. Construction industry is highly volatile on economic downturns an as a result of the recession there was increased unemployment which affected the housing loans and consumer loans. The analyze of the quality of loan portfolio of Serbian banking sector shows that large part of NPL loans are due of excessive risk taking before 2008 when the NPL rate reached $11 \%$. Still, prolonged recession in EU through demand had impact on export and the credit ability of exporters and then the economic downturn affected the rest of corporate sector leaving major consequences on exposure towards construction. The increased unemployment affected especially the consumer loans and credit cards. Macedonian banking sector had lowest effect from the financial crisis but still the trend of deterioration is upward. This is due to the fact, which is confirmed by numerous researches, that the GDP reduction was smaller and accordingly the impact on portfolio quality was smaller. Croatia and Serbia economy had much more detrimental consequences from the financial crisis in 2009 than Macedonian 
economy. GDP reduction off course is connected to macroeconomic policy. Macedonia before the crisis was low indebted country which was used by economic policy makers to increase the debt in crisis in order to overcome the negative impact of the crisis. Also Macedonian economy didn't face with increased unemployment which contributed the quality of retail portfolio to remain stable. Another thing that we must have in mind for the analysis the NPL ratios in the future is the new NPL definition of EBA (EBA, 2013) which is more rigid than the current NPL definition in sample countries.

The challenge for all three countries in the future is how to encourage growth in the real sector. If the low rates of growth of the loan portfolio of companies continue, then it will continue the trend of deterioration of its quality. With some time lag the quality of retail portfolio will deteriorate. Also another issue that the sample jurisdictions must solve is how to create more incentives to have faster resolving of bad loans.

\section{References}

Central Bank of Croatia. (2013). Financial stability report for 2012. (No.11, VII 2013). Zagreb: Publishing Department.

Central Bank of Croatia. (2014). Banks Bulletin for 2013. (No.26, VIII 2014). Zagreb: Publishing Department.

Central Bank of Croatia. (2014). Financial stability report for 2013. (No.13, VII 2014). Zagreb: Publishing Department.

Central Bank of Serbia. (2014). Annual Financial Stability Report - 2013. (ISSN 2217-6942). Belgrade: Publishing Department.

Central Bank of Serbia. (2014). Banking sector of Serbia, Fourth Quarter Report 2013. Belgrade: Publishing Department.

Delova-Jolevska, E., \& Andovski, I. (2014). The Future Development of the Service Sector and it's Impact on the Banking industry. The Case Of Macedonia. EMC Review-Časopis za ekonomiju-APEIRON, 7(1).

EBA. (2013). Implementing Technical Standards on supervisory reporting of forbearance and non-performing exposures under article 99(4) of Regulation (UE) 575/2013 [EBA/ITS/2013/03]. Brussels.

ECB. (2013). Non-performing loans - What matters in addition to the economic cycle? (No.1515). Frankfurt am Main.

Espinoza, R. A., \& Prasad, A. (2010). Nonperforming loans in the GCC banking system and their macroeconomic effects. IMF Working Papers, 1-24.

European Banking Coordination “Vienna”Initiative. (2012). Working Group on NPLs in Central, Eastern and Southeastern Europe. Vienna.

Filipović, M., \& Hadžić, M. (2012). Banking Sector in Serbia: Impacts of late transition and Global Crisis. Overcoming the Crisis, 65.

Glen, J. \& Mondragón-Vélezand, C. (2011). Credit risk management in UK banking sector. Assignment Source, 24(5). 
Hou, Y., \& Dickinson, D. (2007). The non-performing loans: some bank-level evidences. In 4th International Conference on Applied Financial Economics, Samos Island, Greece.

IMF. (2013). Non-Performing Loans in CESEE: Determinants and Impact on Macroeconomic Performance. (WPIEA2013072). Washington.

Louzis, D. P., Vouldis, A. T., \& Metaxas, V. L. (2012). Macroeconomic and bankspecific determinants of non-performing loans in Greece: A comparative study of mortgage, business and consumer loan portfolios. Journal of Banking \& Finance, 36(4), 1012-1027.

Nađa, D. (2012). Evaluation of Financial Performance of Banking Sector: Evidence from Bosnia and Herzegovina, Croatia, Serbia and Slovenia. Journal of Economic and Social Studies, 2(2).

NBRM. (2011). Report on the risks in the banking system of the Republic of Macedonia 2010. Skopje: Publishing Department.

NBRM. (2012). Report on the risks in the banking system of the Republic of Macedonia 2011. Skopje: Publishing Department.

NBRM. (2013). Report on the risks in the banking system of the Republic of Macedonia 2012. Skopje: Publishing Department.

NBRM. (2014). Report on the risks in the banking system of the Republic of Macedonia 2013. Skopje: Publishing Department.

Raiffesein Research. (2014). CEE Banking Sector Report for 2013. Vienna: Raiffeisen Bank International AG.

Unemployment rate on Macedonia, Serbia and Croatia. Retrieved May 2014 from www.tradingeconomics.com

World Bank. (2014). World Bank statistics. Retrieved from http://data.worldbank. org/. 